\title{
Diversified Hydrophytes in Different Aquatic Habitats of Puri District, Odisha, India
}

\author{
Bandita Kumari Dalasingh ${ }^{1}$, Sagarika Parida ${ }^{1}$, Dipankar Bhattacharyay ${ }^{2}$, Gyanranjan Mahalik ${ }^{1, *}$ \\ ${ }^{1}$ Department of Botany, School of Applied Sciences, Centurion University of Technology and Management, Odisha, India \\ ${ }^{2}$ School of Applied Sciences, Centurion University of Technology and Management, Odisha, India
}

Received October 6, 2019; Revised October 30, 2019; Accepted November 10, 2019

Copyright $\odot 2019$ by authors, all rights reserved. Authors agree that this article remains permanently open access under the terms of the Creative Commons Attribution License 4.0 International License

\begin{abstract}
Hydrophytes are water loving plants that regulate the aquatic ecosystem. Variety and variability of hydrophytic plants have a great role in balanced aquatic ecosystem. The study revealed that a total 60 species of hydrophytes belonging to 39 genera and 25 families were identified. Among these, Cyperaceae was the dominant family comprising 17 species, out of which, monocots represented by 33 species belonging to 19 genera and 9 families; dicots represented by 24 species belonging to 17 genera and 14 families; pteridophyta represented by 3 species belonging to 3 genera and 2 families. The monocotyledon was found to be the dominant class. In the documented species, 55 herbs, 2 shrubs and 3 ferns were recorded with a variable habitat viz. 35 marshy, 8 amphibious, 6 submerged, 6 free floating and 5 fixed floating species. Documented plants were preserved as herbarium with their botanical names, family, local names and habitat. Two RET (Rare, Endanger and Threatened) category plant species viz. Wolffia arrhiza (L.) Horkel ex Wimm. and Lindernia anagallis (Burm.f.) Pennell belonging to Araceae and Scrophulariaceae family respectively were documented from Gadakharad village during the study which is the unexplored area and no documentation was done previously. Therefore, these species should be conserved by taking proper care of the water body otherwise the day will come and these two plants will be in verge of extinction. The present work exhibited the database of hydrophytes in Puri district of Odisha which will help in future work for its conversation and to maintain the local biodiversity.
\end{abstract}

Keywords Amphibious, Cyperaceae, Monocots, Pteridophyta, Hydrophytes, RET (Rare, Endanger and Threatened)

\section{Introduction}

Phytodiversity refers to the variety and variability of plants, i.e. the number of types or taxa in a given region or group which can be measured at any level from overall global diversity to ecosystem, community, species, populations, individuals and even to genes within a single individual that help us to understand the basic aspects of biology such as speciation, isolation, endemism and evolution [1]. The hydrosphere of the earth is composed of all water bodies includes oceans, rivers, ponds, lakes, ditches, streams etc. [2]. Aquatic plants are plants that have adapted to living in aquatic environments is called hydrophytes which can only grow in water or in soil that is permanently saturated with water and can able to change the physico-chemical characteristics of pond water. It plays a major role in primary productivity of the aquatic ecosystem. The hydrophytes are submerged, free floating, fixed floating, marshy and amphibious in nature [3]. They are one of the important biotic entities in aquatic ecosystem which provide food, oxygen and shelter to the other aquatic organisms [4] and are essential to prevent too much turbidity and erosion of soil and to maintain the delicate balance of nutrients in water [5]. Works on floristic study of composition of hydrophytes in different water reservoirs in different parts of Abroad, India and Odisha were carried out by several workers [6-8]. Many water bodies present in Puri district and its adjoining territory containing a wide scope of hydrophytes which has not been investigated. So a broad investigation of hydrophytes of this area was done to observe the detail record of the distribution of hydrophytes, their habitat ecology and association. This may have economic and medicinal significance.

\section{Materials and Methods}

\subsection{Study Area}

Puri is a coastal district of the Odisha state of India. This district comprises 1722 revenue villages (fig.1). Puri district is located between 19.817743 latitude and 
85.828629 longitudes. It is located in India, in the cities place category with the GPS coordinates of $19^{\circ} 49^{\prime} 3.8748^{\prime \prime}$ $\mathrm{N}$ and $85^{\circ} 49^{\prime} 43.0644^{\prime \prime} \mathrm{E}$. The climate of this district is characterized by seasonal climatic condition and intermediate temperature. The summer months are hot while the winter months are cool.

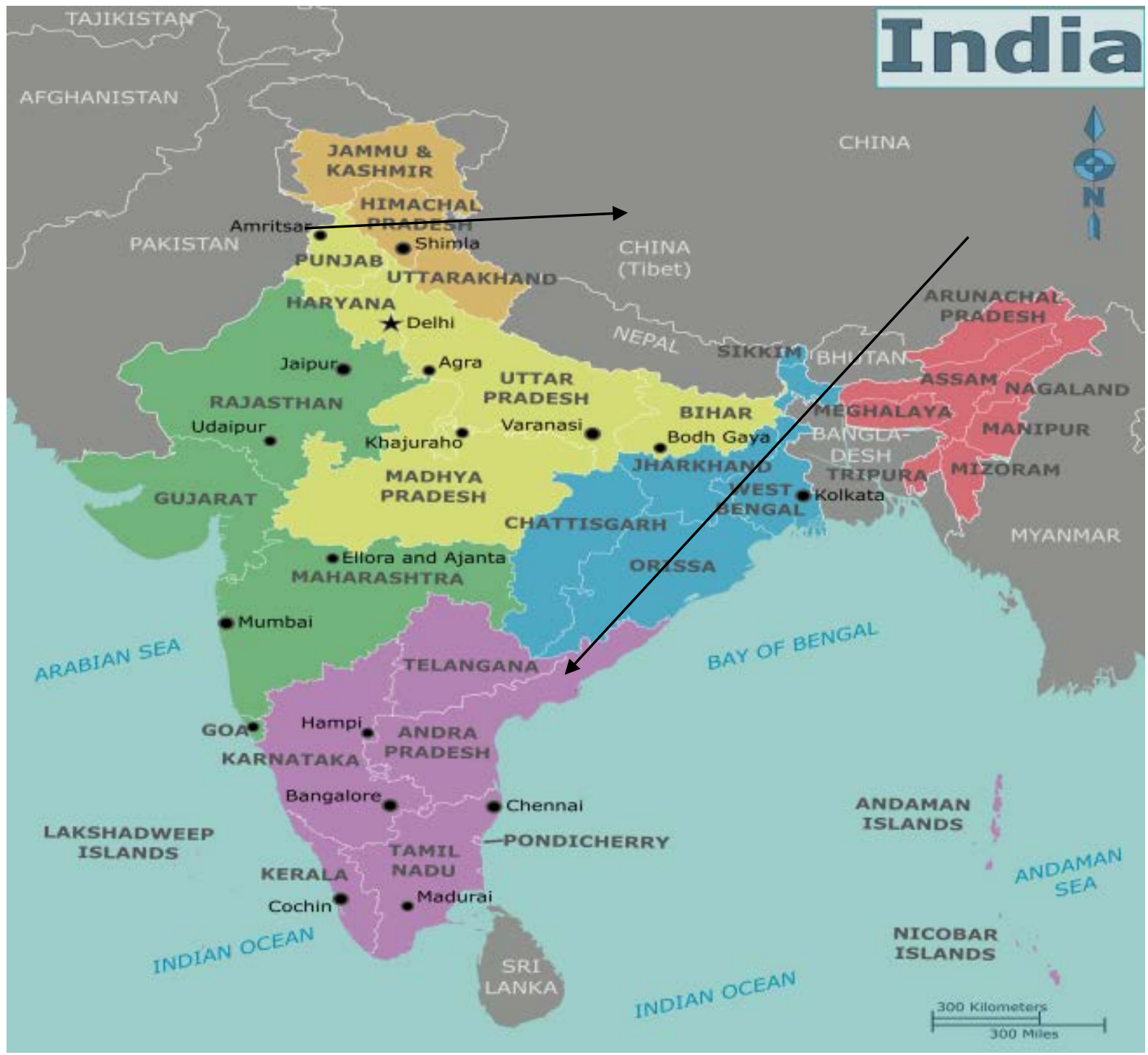



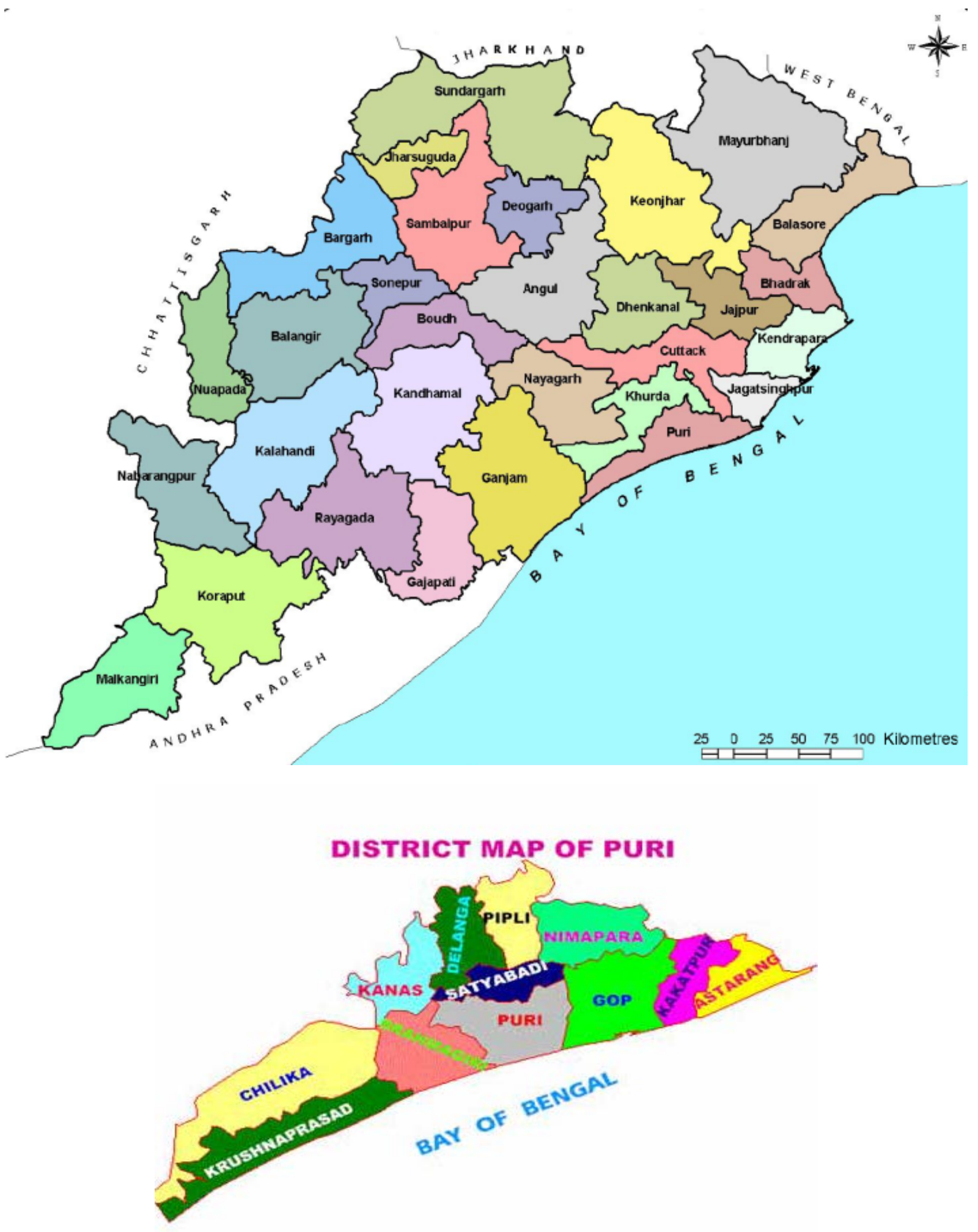

Figure 1. Map of study area 


\subsection{Survey}

The studies of hydrophytes were conducted during September 2017 to May 2019 in Puri district of Odisha, India. The climate of this study area is characterized by seasonal climatic condition and intermediate temperature. The summer months are hot while the winter months are cool. Many water bodies are present in the study area that favors the occurrence of a rich aquatic flora which get filled up with water during monsoon season, water may persist for a considerably long-time whereas some are dry out during summer season. Total of 20 water bodies were observed during the survey of hydrophytes in 5 villages having total 9 large and 11 small ponds (Table 1) in different seasons especially immediate after rainy season in the month of September and during summer season at fortnightly interval. Specimens were collected in lowering and fruiting time carefully for authenticated identification of the species and photographs were taken at the survey site to document the hydrophytes for its abundance and distribution (Figure 2). Special emphasis was given to find

out the RET (Rare, Endangered and Threatened) plants. The collected specimens were identified taxonomically with the help of "The Botany of Bihar and Orissa" [9] and "The Flora of Orissa" [8]. The identified plants species were authenticated and deposited in the form of herbarium at Department of Botany, School of Applied Sciences, Centurion University of Technology and Management, Odisha, India.

Table 1. Villages having different types of water body

\begin{tabular}{|c|c|c|c|}
\hline Sl.No. & Village Name & \multicolumn{2}{|c|}{ Ponds } \\
\hline & & Large pond & Small pond \\
\hline & Garhkharad & 2 & 3 \\
\hline & Badurabara & 2 & 2 \\
\hline & Biratoi & 2 & 1 \\
\hline & Bajapadar & 2 & 3 \\
\hline & Telangapada & 1 & 2 \\
\hline & Total & 9 & 11 \\
\hline
\end{tabular}
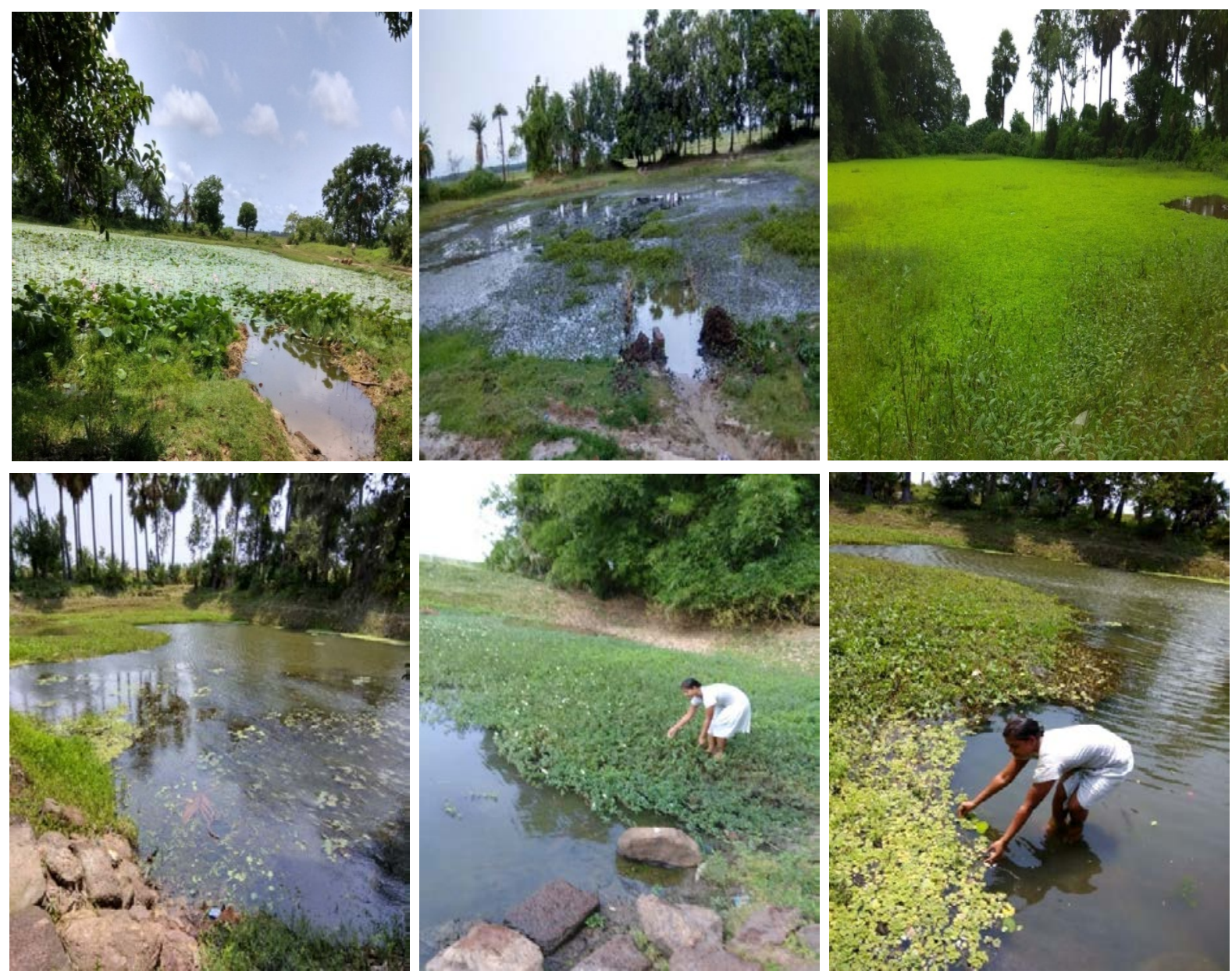

Figure 2. During field survey and plant collection 


\section{Results and Discussion}

The results of the present study revealed that a total number of 60 species were recorded belonging to 39 genera of 25 families surveyed from 11 small and 9 large ponds from 5 villages of Puri district (Table 1). List of hydrophytes including their genus, species, family, local name and habitat were recorded (Table 2) and plant group, i.e. pteridophyta, dicotyledon and monocotyledon was given in figure 3. The dominant families are Cyperaceae with 4 genera and 17 species, followed by Poaceae with 5 genera and 5 species, Onagraceae and Scrophulariaceae belongs to 1 genera and 3 species each, Asteraceae and Hydrocharitaceae belongs to 3 genera and 3 species each, Amaranthaceae, Commelinaceae, Convolvulaceae and Nymphaeaceae belongs to 1 genera and 2 species each, Araceae, Rubiaceae and Salviniaceae belongs to 2 genera and 2 species each, whereas 12 families represented by a single species each i.e. Aponogetonaceae, Characeae, Fabaceae, Lentibulariaceae, Lythraceae, Marsileaceae, Menyanthaceae, Nelumbonaceae, Polygonaceae, Pontederiaceae, Typhaceae, Verbenaceae (Figure 4 \& Table 3).

Table 2. List of Hydrophytic plants of Puri, Odisha

\begin{tabular}{|c|c|c|c|c|}
\hline Sl. No. & Botanical Name & Family & Local Name & Habitat \\
\hline 1. & Alternanthera philoxeroides (Mart.) Griseb. & Amaranthaceae & - & Amphibious \\
\hline 2. & Alternanthera sessilis (L.) R. Br. ex DC. & Amaranthaceae & Madaranga saga & Marshy \\
\hline 3. & Aponogeton natans (L.) Engl. \& K.Krause & Aponogetonaceae & Ghechu & Submerged \\
\hline 4. & Pistia stratiotes L. & Araceae & Bora jhanji & Free floating \\
\hline 5. & Wolffia arrhiza (L.) Horkel ex Wimm. & Araceae & Panidala & Free floating \\
\hline 6. & Eclipta prostrata (L.) L. & Asteraceae & Bhringraj & Marshy \\
\hline 7. & Emilia sonchifolia (L.) DC. ex Wight & Asteraceae & Sarkara & Marshy \\
\hline 8. & Spilanthes paniculata Wall. ex DC. & Asteraceae & - & Marshy \\
\hline 9. & Chara vulgaris $\mathrm{L}$. & Characeae & - & Submerged \\
\hline 10. & Commelina benghalensis L. & Commelinaceae & Kaniseera & Marshy \\
\hline 11. & Commelina paludosa $\mathrm{Bl}$. & Commelinaceae & - & Marshy \\
\hline 12. & Ipomoea aquatica Forssk. & Convolvulaceae & - & Marshy \\
\hline 13. & Ipomoea carnea Jacq. & Convolvulaceae & Amari & Marshy \\
\hline 14. & Bulbostylis barbata (Rottb.) C.B.Clarke & Сyperaceae & - & Marshy \\
\hline 15. & Bulbostylis capillaris (L.) Kunth ex C.B.Clarke & Cyperaceae & - & Marshy \\
\hline 16. & Bulbostylis densa (Wall.) Hand.-Mazz. & Сyperaceae & - & Marshy \\
\hline 17. & Cyperus amabilis Vahl & Cyperaceae & - & Marshy \\
\hline 18. & Cyperus brevifolius (Rottb.) Hassk. & Cyperaceae & Harit mutha & Marshy \\
\hline 19. & Cyperus compressus L. & Cyperaceae & - & Marshy \\
\hline 20. & Cyperus distans L.f. & Сyperaceae & - & Marshy \\
\hline 21. & Cyperus halpan L. & Cyperaceae & - & Marshy \\
\hline 22. & Cyperus haspan L. & Cyperaceae & - & Marshy \\
\hline 23. & Cyperus iria L. & Cyperaceae & Swanti & Marshy \\
\hline 24. & Cyperus kyllingia Endl. & Cyperaceae & - & Marshy \\
\hline 25. & Cyperus polystachyos Rottb. & Cyperaceae & - & Marshy \\
\hline 26. & Cyperus rotundus L. & Cyperaceae & Mutha & Marshy \\
\hline 27. & Fimbristylis argentea (Rottb.) Vahl & Cyperaceae & - & Marshy \\
\hline 28. & Fimbristylis dichotoma (L.) Vahl & Сyperaceae & - & Marshy \\
\hline 29. & Fimbristylis miliacea (L.) Vahl & Cyperaceae & Swanli & Marshy \\
\hline 30. & Schoenoplectiella articulata (L.) Lye & Cyperaceae & - & Marshy \\
\hline 31. & Aeschynomene aspera L. & Fabaceae & Sola & Amphibious \\
\hline 32. & Hydrilla verticillata (L.f.) Royle & Hydrocharitaceae & Chingudia dala & Submerged \\
\hline 33. & Najas graminea Delile & Hydrocharitaceae & - & Submerged \\
\hline 34. & Ottelia alismoides (L.) Pers. & Hydrocharitaceae & Pani kundri & Submerged \\
\hline
\end{tabular}




\begin{tabular}{|c|c|c|c|c|}
\hline 35. & Utricularia stellaris L.f. & Lentibulariaceae & Bhaturia dala & Submerged \\
\hline 36. & Trapa natans L. Var. bispinosa (Roxb.) Makino & Lythraceae & Pani singada & Free floating \\
\hline 37. & Marsilea quadrifolia $\mathrm{L}$. & Marsileaceae & - & Amphibious \\
\hline 38. & Nymphoides hydrophylla (Lour.) Kuntze & Menyanthaceae & Chandra-malla & Fixed floating \\
\hline 39. & Nelumbo nucifera Gaertn. & Nelumbonaceae & Padma & Fixed floating \\
\hline 40. & Nymphaea pubescens Willd. & Nymphaeaceae & Nilakain & Fixed floating \\
\hline 41. & Nymphaea pubescens Willd. & Nymphaeaceae & Dhalakain & Fixed floating \\
\hline 42. & Ludwigia adscendens (L.) H.Hara & Onagraceae & Jagal & Fixed floating \\
\hline 43. & Ludwigia octovalvis (Jacq.) P.H.Raven & Onagraceae & Panilabanga & Amphibious \\
\hline 44. & Ludwigia perennis L. & Onagraceae & - & Amphibious \\
\hline 45. & Alloteropsis cimicina (L.) Stapf & Poaceae & - & Amphibious \\
\hline 46. & Brachiaria mutica (Forssk.) Stapf & Poaceae & Para grass & Marshy \\
\hline 47. & Echinochloa colona (L.) Link & Poaceae & Swanghasa & Marshy \\
\hline 48. & Oryza rufipogon Griff. & Poaceae & Balunga & Marshy \\
\hline 49. & Paspalum distichum L. & Poaceae & - & Marshy \\
\hline 50. & Polygonum plebeium R.Br. & Polygonaceae & Muthi saga & Amphibious \\
\hline 51. & Eichhornia crassipes (Mart.) Solms & Pontederiaceae & Bilati dala & Free floating \\
\hline 52. & Dentella repens (L.) J.R.Forst. \& G.Forst. & Rubiaceae & - & Marshy \\
\hline 53. & Hedyotis corymbosa (L.) Lam. & Rubiaceae & Taraka punji & Marshy \\
\hline 54. & Azolla pinnata R. Br. & Salviniaceae & Chuni dala & Free floating \\
\hline 55. & Salvinia cucullata Roxb. ex Bory & Salviniaceae & - & Free floating \\
\hline 56. & Lindernia anagallis (Burm. f.) Pennell & Scrophulariaceae & - & Marshy \\
\hline 57. & Lindernia ciliata (Colsm.) Pennell & Scrophulariaceae & - & Marshy \\
\hline 58. & Lindernia crustacea (L.) F.Muell. & Scrophulariaceae & - & Marshy \\
\hline 59. & Typha angustata Bory \& Chaub. & Typhaceae & Hangla & Amphibious \\
\hline 60. & Phyla nodiflora (L.) Greene & Verbenaceae & Jala pippali gosingi & Marshy \\
\hline
\end{tabular}

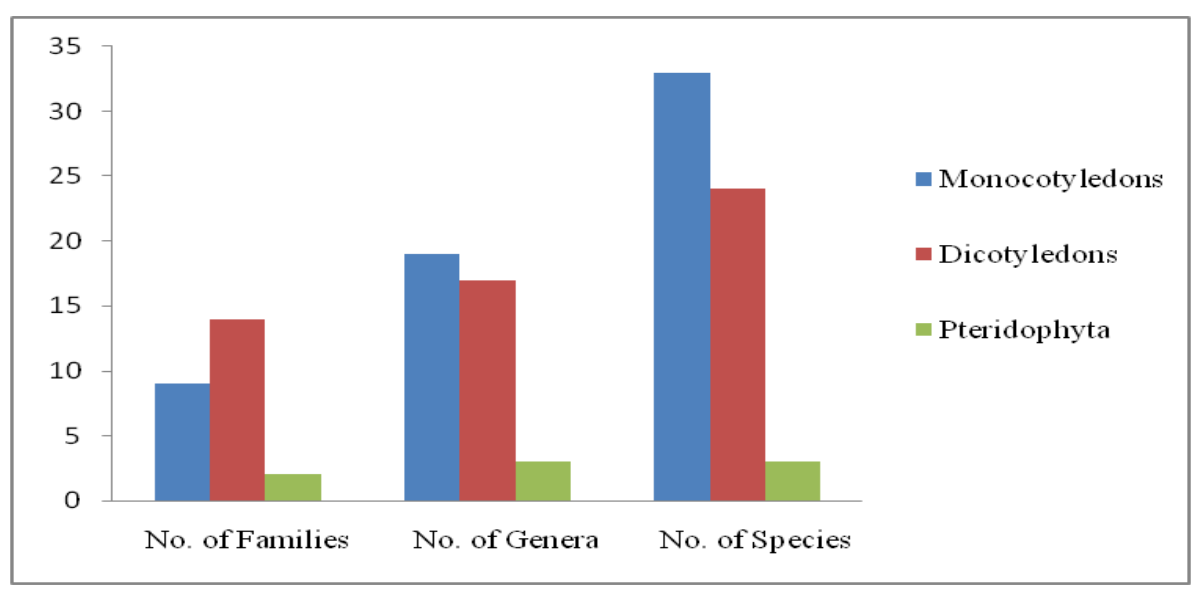

Figure 3. List of division-wise distribution of hydrophytic plants present in Puri district, Odisha

Table 3. List of habitat-wise distribution of hydrophytic plants present in Puri district, Odisha

\begin{tabular}{|c|c|c|c|}
\hline Habitat & No. of Families & No. of Genera & No. of Species \\
\hline Marshy & 9 & 18 & 85 \\
\hline Amphibious & 7 & 7 & 6 \\
\hline Submerged & 4 & 6 & 6 \\
\hline Free floating & 4 & 4 & 5 \\
\hline Fixed floating & 4 & 6 & 8 \\
\hline
\end{tabular}




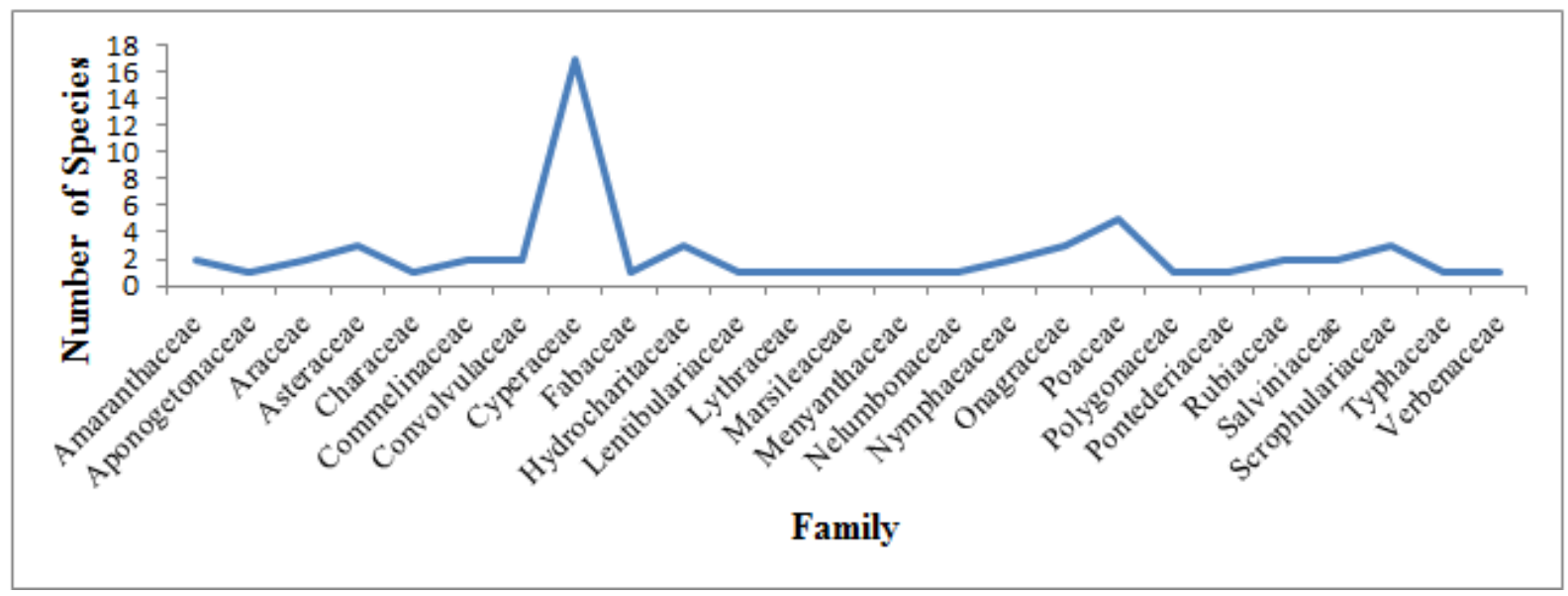

Figure 4. List of family-wise distribution of hydrophytic plants present in Puri district, Odisha

Several works on aquatic flora were carried out in India and also in the different districts of Odisha. Earlier a total of 8 plant species belonging to 8 different genera and 8 families were reported in Tripura, India [10]. Aquatic macrophytes comprises a total of 132 species included 129 flowering plants and 3 Pteridophyte taxa spread in 82 genera and 41 families were recorded in Balasore district of Odisha, eastern India. The most specious families were Cyperaceae with 27 species followed by Poaceae (24) and the other dominant families are Linderniaceae, Fabaceae, Onagraceae, Polygonaceae, Commelinaceae, and Scrophulariaceae [11]. Floral diversity of Bhubaneswar and its adjoining villages, Odisha composed of a total number of 102 species were recorded belonging to 64 genera of 34 families, of which 8 species are submerged hydrophytes, 9 species are free floating, 9 species are fixed floating, 21 species are amphibious hydrophytes and 55 species are marshy hydrophytes [12]. The floral diversity and distribution of vascular macrophytes in Ansupa Lake, Odisha composed of a total of 244 macrophyte species that included 182 semi-aquatic and 62 obligatory aquatic macrophytes. Out of which, 35\% submerged, $15 \%$ free floating, 31\% rooted floating and 19\% marshy plant species [13].

During survey the most dominant genera are Cyperus (Cyperaceae) with 10 species recorded, followed by Bulbostylis (Cyperaceae), Fimbristylis (Cyperaceae), Ludwigia (Onagraceae) and Lindernia (Scrophulariaceae) with 3 species each, 4 genera: Alternanthera (Amaranthaceae), Commelina (Commelinaceae), Ipomoea (Convolvulaceae) and Nymphaea (Nymphaeaceae) were represented by 2 species each, 30 genera: Aponogeton (Aponogetonaceae), Pistia (Araceae), Wolffia (Araceae), Eclipta (Asteraceae), Emilia (Asteraceae), Spilanthes (Asteraceae), Chara (Characeae), Schoenoplectiella (Cyperaceae), Aeschynomene (Fabaceae), Hydrilla (Hydrocharitaceae), Najas (Hydrocharitaceae), Ottelia (Hydrocharitaceae), Utricularia (Lentibulariaceae), Trapa (Lythraceae), Marsilea (Marsileaceae), Nymphoides
(Menyanthaceae), Nelumbo (Nelumbonaceae), Alloteropsis (Poaceae), Brachiaria (Poaceae), Echinochloa (Poaceae), Oryza (Poaceae), Paspalum (Poaceae), Polygonum (Polygonaceae), Eichhornia (Pontederiaceae), Dentella (Rubiaceae), Hedyotis (Rubiaceae), Azolla (Salviniaceae), Salvinia (Salviniaceae), Typha (Typhaceae) and Phyla (Verbenaceae) were represented by single species each.

The total observed species, monocots were represented by 33 species belonging to 19 genera and 9 families, while dicots contributed by 24 species belonging to 17 genera and 14 families and 3 species belonging to 3 genera and 2 families of Pteridophyta were recorded.

The present work was carried out for the first time to study about the occurrence of different hydrophytes with special reference to rare species in Gadakhara dvillage of Puri district of Odisha. The occurrence of RET (Rare, Endanger and Threatened) category plant species viz. Wolffia arrhiza (L.) Horkel ex Wimm. and Lindernia anagallis (Burm.f.) Pennell belonging to Araceae and Scrophulariaceae family respectively. These RET Category species were noticed and documented for the first time in this area. There is a need to protect and conserve these species for the future generation to balance fresh water ecosystem and this will definitely help to maintain other ecosystem and their by inducing the sustainability.

\section{Conclusions}

Global biodiversity monitoring is providing information on the number and distribution of species, enabling governments to protect villages with high levels of biodiversity and containing rare and threatened species. The current study revealed that wide ranges of hydrophytes are documented in different water bodies of Puri district especially in the village of Gadakharad. The present study gives an idea of existing plants in this study area which revealed that, 60 hydrophytes belonging to 39 genera under 25 families were studied out of that two RET species viz. 
Wolffia arrhiza (L.) Horkel ex Wimm. and Lindernia anagallis (Burm.f.) Pennell belonging to Araceae and Scrophulariaceae family respectively were first time recorded in Gadakharad village. The data presented in this work are original and first hand. This study provides basic information on the present status and composition of hydrophytes in Puri district of Odisha. There is a need to be protected and conserve this species for the future generation. The present work exhibited the database of hydrophytes which will help in future work for its conservation, preservation and addition of the local biodiversity.

\section{Acknowledgements}

The authors would like to thank the villagers of the survey area of Puri district, Odisha. The authors are also grateful to the HOD, Department of Botany and Dean, School of Applied Sciences, Centurion University of Technology and Management (CUTM), Odisha, India for their kind help and suggestions to carry out research work successfully.

\section{REFERENCES}

[1] A. K. Mishra, M.P. Sharma, H. Singh. Floristic diversity of Delhi, India: A checklist, International Journal of Herbal Medicine, Vol. 3(4 Part A), 8-18, 2015.

[2] T. Jagdishprasad. Biodiversity of aquatic plants of Shivnibandh lake of Sakoli tehsil of Bhandara district of MS, India, International Journal of Life Sciences, Vol. A, 2, 211-213, 2014

[3] P. I. Khaparde, N. V. Harney. Macrophytes diversity of Ghodpeth Lake near Bhadrawati, District-Chandrapur (M.S.), India. International Research Journal of Science \& Engineering, Vol. 6, No. 2, 40-42, 2018.

[4] B. M. Reddy, A. Chaturvedi. Study of Aquatic and Associated Macrophytes from the major Rivers of the Chandrapur District, Maharashtra. International Journal of Science, Environment and Technology, Vol. 5, No. 6, 3774-3782, 2016.

[5] K. Ishaq, S. K. Marwat, N. K. Mandokhel. Preliminary Study of Aquatic and Marshland Angiosperms of Zhob District, Balochistan, Pakistan, Pakistan Journal of Botany, Vol. 49, No. 2, 715-723, 2017.

[6] H. B. Pattnaik, G. L. Patro, G. C. Tosh. Major distribution of aquatic weed flora in the district Ganjam, Odisha, Proceeding 8th Annual Conference, Odisha Botanical Society (Rayagada), 1983.

[7] M. Mohanty, B. P. Choudhury. Addition to Hydrophytes of Cuttack. Bulletin of Envernmental studies, Vol. 1, 9-12, 1984.

[8] H. O. Saxena, M. Brahmam. The Flora of Orissa, Vol. 1-4.
Regional Research Laboratory (CSIR), Bhubaneswar and Orissa forest Development Corporation Ltd., Bhubaneswar, 1994.

[9] H. H. Haines. The Botany of Bihar and Odisha. 1-6 parts, London, 1925.

[10] S. Bhowmik, and B. K. Datta. Elemental analysis of some ethnomedicinaly important hydrophytes and marsh plants of India used in traditional medicine. Asian Pacific Journal of Tropical Biomedicine, Vol. 2, No. 3, S1227-S1231, 2012.

[11] K. A. Sujana, R. Saravanan, A. D. Pandey. Distribution of Aquatic Macrophytes in Balasore District, Odisha, In Aquatic Ecosystem: Biodiversity, Ecology and Conservation, 1-12, 2015.

[12] S. Subhadarsini, S. K Nayak, K. B. Satapathy. Study of Floral Diversity with Special Reference to Hydrophytes in Bhubaneswar and its Adjoining Villages, Odisha, India, International Research Journal of Biological Sciences, Vol. 5, No. 9, 1-7, 2016.

[13] M. Panda, R. N. Samal , K. S. Bhatta, S. Lenka, J. Rout , H. K. Patra , S. Nanda. Diversity and distribution of vascular macrophytes in Ansupa Lake, Odisha, India, Bonorowo Wetlands, Vol. 8, No. 1, 1-12, 2018. 